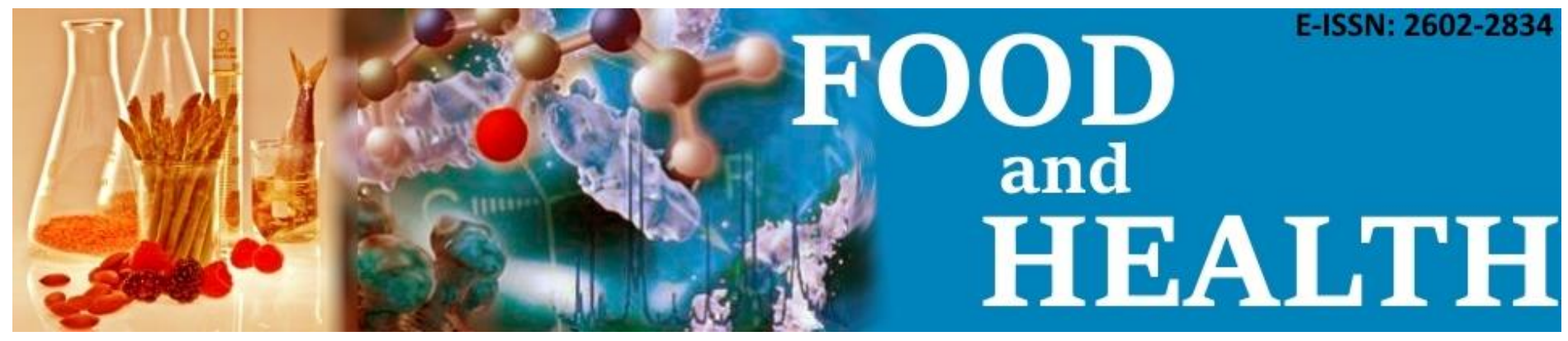

\title{
DETERMINATION OF ORGANOCHLORINATED PESTICIDE AND POLYCHLORINATED BIPHENYL CONGENERS RESIDUES IN CHICKEN EGGS BY GAS CHROMATOGRAPHY
}

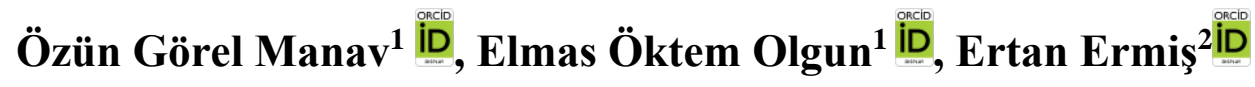

Cite this article as:

Görel Manav, Ö., Öktem Olgun, E., Ermiş, E. (2018). Determination of organochlorinated Pesticide and Polchlorinated Biphenyl Congeners Residues in Chicken Eggs by Chromatography. Food and Health, 4(4), 264-273. DOI: 10.3153/FH18026

\footnotetext{
1 The Scientific and Technological Research Council of Turkey (TÜBITAK), Marmara Research Center, Food Institute, P.K. 21, 41470 Gebze, Kocaeli, Turkey

2 Istanbul Sabahattin Zaim University, Faculty of Engineering and Natural Sciences, Food Engineering Department, Halkalı, 34303, İstanbul, Turkey
}

Submitted: 07.12.2017

Accepted: 25.02 .2018

Published online: 31.05.2018

Correspondence:

Ertan ERMIŞ

E-mail: ertan.ermis@gmail.com

๑Copyright 2018 by ScientificWebJournals Available online at http://jifhs.scientificwebjournals.com

\begin{abstract}
The aim of this study was to determine the concentrations of organochlorinated pesticides (OCPs) and polychlorinated biphenyls (PCBs) congeners in chicken eggs obtained from various locations in Turkey by gas chromatography and valitadion of the results using different detector systems (MS, MS/MS and ECD). In total, eighteen OCP and PCB compounds were analysed in hundred egg samples. Only $\beta-\mathrm{HCH}, 4,4-\mathrm{DDE}$ and PCB138 were found in nine egg samples at concentrations of $5.1-7.2 \mu \mathrm{g} / \mathrm{kg}, 8.4-30 \mu \mathrm{g} / \mathrm{kg}$ and $4.2 \mu \mathrm{g} / \mathrm{kg}$ respectively. The detected concentrations of these compounds were found to be lower than the maximum residue levels (MRLs) set by EU. The recoveries, relative standard deviations (RSD), limit of detection (LOD) and limit of quantification (LOQ) were found in the range of $83-111 \%, 0.9-14.1 \%, 1.2-3.5 \mu \mathrm{g} / \mathrm{kg}$ and $0.3-10.0 \mu \mathrm{g} / \mathrm{kg}$ respectively.
\end{abstract}

Keywords: Organochlorinated pesticides, Polychlorinated biphenyls, Chicken egg, Gas chromatography 


\section{Introduction}

Environmental contamination of persistent organic compounds (POPs) has been widely reported and documented (Virgínia C Fernandes et al., 2011; Ritter et al., 1995). Polychlorinated biphenyls (PCBs) and organochlorinated pesticides (OCPs) are semi volatile, ubiqutous compounds and resistant to biochemical and physical degredation mechanisms (Mansilha et al., 2010; Ritter et al., 1995). They can be accumulated in adipose tissues and fat layers of organisms due to their lipophylic structure (Ritter et al., 1995; Vallack et al., 1998). Exposure to these compounds may lead to cancer formation, neurotoxic disorders, reproductive and behavioral adverse effects (Mansilha et al., 2010). Since these compounds can be accumulated in fat, they can be delivered through foods having certain amount of fat to the human beings (Bernhoft et al., 1997; Polder et al., 2016). They can still be found in the environment and in food materials at levels that may cause harmful effects on human health (such as disruption of hormonal activity) due to their persistent and lipophylic nature despite the production and use of these toxic substances have been banned or restricted in most countries since early 1970s (Virgínia C Fernandes et al., 2011). It has been reported that residual distribution of these pollutants such as dichlorodiphenyltrichloroethane (DDT), PCBs, dieldrin, chlordane, hexachlorobenzene (HCB) and hexachlorohexanes $(\mathrm{HCH})$ are widely found in foods containing fat (Jeong et al., 2014; Liu et al., 2007). Some studies have revealed their occurence in dairy products such as cheese, milk, butter, yoghurt (Keikotlhaile et al., 2010; Salem et al., 2009) and in human milk (Çok et al., 2011; Nasir et al., 1998) as well. Substances reported to be found in these foods include $\mathrm{HCHs}$, DDTs and endosulfan.

Exposure to OCPs and PCBs and accumulation in the adipose tissues occurs through the food chain contamination and environmental pollution (Ahmad et al., 2010). Pesticide contamination from pesticide containing feeds to chicken meat and egg has been reported (Aulakh et al., 2006; Kilic et al., 2011; Olanca et al., 2014; Tao et al., 2009). OCP residues in feed material ingested by chickens and therefore results in the occurence in meat tissues and eggs which are then consumed by consumers. Due to their lipophylic structure, they tend to be accumulated in body tissues. According to some researchers, the proportions of intake of DDTs and $\mathrm{HCHs}$ into the body through inhalation and dermal contact are $5.1 \%$ and $13.5 \%$ of the total intakes respectively, Ingestion through diet was reported as around $94.9 \%$ of the total (Kilic et al., 2011).

Chicken egg, and chicken meat tend to be the most popular food items in many countries. However, these food materials are reported as main sources of OCPs by researchers worldwide (Aulakh et al., 2006; Darko \& Acquaah, 2007; Fontcuberta et al., 2008) due to their significant amount of fat components. Therefore, regular screening of these foodstuffs is necessary to inform both the consumers and traders to inctease the level of awareness. Although the contamination and toxicity of OCPs and PCBs have been extensively investigated in many developed countries, very few studies are available in the literature on OCP and PCB levels in foods in Turkey (Kilic et al., 2011). Thus, this work was carried out to investigate the degree of contamination with $\mathrm{HCH}$-isomers, heptachlor, aldrin, dieldrin, hekzachlorobenzene, total DDT and polychlorinated biphenyls (PCBs) congener's residues in chicken eggs.

The maximum residue levels (MRLs) for pesticide residues in various foodstuff permitted in the EU are given in respective legislations. The MRLs in Turkish legislation are the same as in EU legislation. The MRLs for OCP and PCB compounds investigated in this study were set as varied from 10 to $50 \mu \mathrm{g} / \mathrm{kg}$ for different compounds (Table 1) (EC 2005; 2008; 2011; Turkish Legislation 2011).

Table 1. MRL values set by EU

\begin{tabular}{lcc}
\hline Compound Name & $\begin{array}{c}\text { MRL } \\
(\boldsymbol{\mu g} / \mathbf{k g})\end{array}$ & EC regulation No \\
\hline Aldrin & 20 & Reg. (EC) No 839/2008 \\
$\alpha-\mathrm{HCH}$ & 20 & Reg. (EC) No 149/2008 \\
$\beta-\mathrm{HCH}$ & 10 & Reg. (EC) No 149/2008 \\
$\gamma-\mathrm{HCH}$ (lindane) & 10 & Reg. (EC) No 149/2008 \\
Dieldrin & 20 & Reg. (EC) No 839/2008 \\
Heptachlor & 20 & Reg. (EC) No 149/2008 \\
HCB & 20 & Reg. (EC) No 149/2008 \\
Sum of DDT and DDE & 50 & Reg. (EC) No 149/2008 \\
Biphenyl & 10 & Reg. (EU) No 978/2011 \\
\hline
\end{tabular}

The occurence and level of POPs in various food materials has been studied using different analysis methods (BarriadaPereira et al., 2005; Bolanos et al., 2007; Cortes-Aguado et al., 2008; Wong et al., 2010). However, little information about comparison of detection capacities and limits of GC system coupled with different detectors for these substances has been found in the literature (Fernandes et al. 2012; Olanca et al. 2014). In this work GC method using ECD, MS and MS/MS detector systems have been used for determination of PCB and OCP residues in hundred egg samples obtained from different regions of Turkey. The results obtained from different detector systems have been elucidated and discussed. 


\section{Materials and Methods}

\section{Chemicals, Reagents and Standards}

OCPs and PCBs standards [Aldrin, dieldrin, hexachlorobenzene (HCB), $\alpha$-hexachlorocyclohexane $(\alpha-\mathrm{HCH}), \beta$-hekzaklorosiklohekzan $(\beta-\mathrm{HCH}), \gamma$-hekzaklorosiklohekzan $(\gamma$ $\mathrm{HCH}$ ), heptachlor, 4,4-dichlorodiphenyldichloroethylene (4,4DDE), 2,4-dichlorodiphenyltrichloroethane (2,4DDT), 4,4-dichlorodiphenyldichloroethane (4,4DDD), 4,4 dichlorodiphenyltrichloroethane (4,4 DDT), 2,4,4'-Trichlorobiphenyl (PCB28), 2,4,6-Trichlorobiphenyl (PCB30), 2,2',5,5'-Tetrachlorobiphenyl (PCB52), 2,2',4,5,5'-Pentachlorobiphenyl (PCB101), 2,2',3,4,4',5'-Hexachlorobiphenyl (PCB138), 2,2',4,4',5,5'-Hexachlorobiphenyl (PCB153), 2,2',3,4,4',5,5'-Heptachlorobiphenyl (PCB180), 2,2',3,3',4,5,5',6-Octachlorobiphenyl (PCB198)] were obtined from Dr. Ehrenstrofer GmbH (Ausburg, Germany). Isooctane secondary and working calibration standard solutions of OCPs and PCBs were prepared to spike egg samples to the required concentrations. Working solutions were prepared in isooctane at $1000 \mathrm{mg} / \mathrm{L}$. PCB $198(1000 \mathrm{mg} / \mathrm{L}$ in isooctane) purchased as internal standard (IS).

The solvents used (isooctane, petrol ether, and acetone) were pesticide residue analysis grade, obtained from Merck\&Co., Inc. (Kenilworth, N.J., U.S.A). The absorptive materials used in our study were silica gel (60-70 mesh) and alimuna purchased from Merck\&Co., Inc. (Kenilworth, N.J., U.S.A). Silica and alumina were activated after drying at $200^{\circ} \mathrm{C}$ for $15 \mathrm{~h}$ prior to use.

Silanized glass wool (research grade), provided by Serva (Heidelberg, Germany) was used to plug the matrix solidphase dispersion (MSPD) column. Anhydrous sodium sulphate (pro-analysis) were obtained from Merck\&Co., Inc. (Kenilworth, N.J., U.S.A).

\section{Eggs}

100 egg samples were collected from local shops and supermarkets in different locations of Turkey (Table 2) representing various production areas from various regions.

\section{Instruments}

GC-ECD chromatographic analysis of OCPs and PCBs was performed using Shimazdu 14A gas chromatography (Kyoto, Japan) equipped with a 63Ni electron capture dedector (ECD). Analytes were seperated with Zebron ZB-35 column $(30 \times 0.50 \mu \mathrm{mx} 0.25 \mathrm{~mm})$ containing $5 \%$ phenylmethylpolysiloxane with phase thickness of $0.25 \mu \mathrm{m}$ (Phenomenex, U.S.A). The temperature program used for the anaylsis was: from $50^{\circ} \mathrm{C}(3 \mathrm{~min})$ to $170{ }^{\circ} \mathrm{C}(0 \mathrm{~min})$, and to $290^{\circ} \mathrm{C}$ $\left(3 \mathrm{~min}\right.$ ) at $4{ }^{\circ} \mathrm{C} / \mathrm{min}$. The injector was set to $270{ }^{\circ} \mathrm{C}$ in the split mode. Helium was carrier at $2 \mathrm{~mL} / \mathrm{min}$ and nitrogen was used at the make-up gas pressure $75 \mathrm{kPA}$. Idenfitication of peaks was based on comparison of the retention times of compounds in the standard solutions. Quantification of the analyzed compounds was performed using the internal standard and the GC/MS system.

Table 2. The regions where the egg samples collected

\begin{tabular}{llc}
\hline Region & City & $\begin{array}{c}\text { Number of samples } \\
\text { collected }\end{array}$ \\
\hline Black Sea Region & Samsun & 5 \\
Central Anatolia & Karaman & 10 \\
Central Anatolia & Ankara & 5 \\
Central Anatolia & Çorum & 5 \\
Central Anatolia & Kayseri & 10 \\
Central Anatolia & Yozgat & 3 \\
Egean Region & Afyon & 9 \\
Egean Region & Denizli & 7 \\
Egean Region & İzmir & 8 \\
Egean Region & Manisa & 5 \\
Marmara Region & Balıkesir & 10 \\
Marmara Region & Bursa & 7 \\
Marmara Region & İstanbul & 10 \\
Marmara Region & Kirklareli & 3 \\
Marmara Region & Sakarya & 3 \\
\hline
\end{tabular}

GC/MS chromatographic analysis of OCPs and PCBs was done using Thermo DSQ GC/MS instrument (Austin, Texas, U.S.A), equipped with ZB-35 column. Helium was used as the carier at $1.5 \mathrm{~mL} / \mathrm{min}$. The ion source and transfer were kept $280{ }^{\circ} \mathrm{C}$ respectively. Electron impact ionization mode with $70 \mathrm{eV}$ electron energy was selected. The screening analysis was performed in the selected-ion monitoring (SIM) mode monitoring at least two characteristic ion for each compound. In some experiments and for confirmation purpose, scan aquisition mode (m/z 50-450) was used. The oven programme was the same as applied for GC-ECD analysis.

GC-MS/MS analysis was done using Thermo Finnigan Polaris Q Ion Trap instrument (San Jose, CA, USA). The oven programme was the same as applied for GC-ECD analysis. Ion source temperature was set to $250{ }^{\circ} \mathrm{C}$, and transfer line temperature to $280{ }^{\circ} \mathrm{C}$. Emission current was $250 \mu \mathrm{A}$ at SIM mode, and multiplier voltage was $1500 \mathrm{~V}$. 


\section{Solid Phase Preperation for Clean-up}

100 parts by weight of alumina to 8.8 parts of water was added and shaked until the clumpings disappeared. It was kept for 24 hours in the dark at room temperature to equilibrate the final water content at $9 \%$ (Hogendoom and Goewie, 1998). 5.1 grams of silica gel (70-230 mesh) (Merck, Kenilworth, N.J., U.S.A) was weighed and held at $200{ }^{\circ} \mathrm{C}$ for about 15 hours (overnight) in an oven. Then it was placed in the desiccator until cooling to the room temperature.

\section{Sample Preparation}

Sample preparation was done according to the method given elsewhere (Valsamaki et al., 2006). The samples were taken to the laboratory and homogenized using a blender. $20 \mathrm{~g}$ of homogenized sample was taken into a centrifuge tube before adding $30 \mathrm{~mL}$ diethylether. Then the mixture was vortexed for 30 seconds. The tube containing mixture was centrifuged at $4000 \mathrm{rpm}$ for 10 minutes. Diethylether phase was seperated and dried under nitrogen gas flow at $40^{\circ} \mathrm{C}$. The remaining oil part was then passed through alumina and silica gel columns for cleaning-up.

\section{Extraction and Clean-up}

$10 \mu \mathrm{g} / \mathrm{kg}$ of standart solution which was prepared using selected OCPs and PCBs was spiked into $1 \mathrm{~g}$ of oil extracted from egg sample. $2 \mathrm{~mL}$ of petroleum ether was added and vortexed for 30 seconds before transferring into the columns containing varied amounts of alumina/silica and alumina/florisil mixes ( $4 \mathrm{~g}$ alumina/5 $\mathrm{g}$ silica, $4 \mathrm{~g}$ alumina/5 $\mathrm{g}$ florisil, $8 \mathrm{~g}$ alumina/10 $\mathrm{g}$ silica, $8 \mathrm{~g}$ alumina/10 $\mathrm{g}$ florisil). The elutions were mixed with $1 \mathrm{~mL}$ of hexane and analysed using GC-ECD and GC-MS.

\section{Validation}

The analytical method developed for determination of PCBs and OCPs in chicken egg samples was validated according to the EU Decision 2002/657/EC by using GC-ECD and GC-MS. For this purpose, selectivity, specifity, linearity, precision (intra-day and inter-day reproducibility) accuracy were determined. Also in GC-MS/MS recovery was studied for confirmation of three instruments RSDs.

\section{Results and Discussion}

The tests were conducted using GC-ECD and GC-MS in three replicates and $\%$ recoveries were calculated as given in Table 3. According to the results obtained from GC-ECD analysis, it can be stated that using $8 \mathrm{~g}$ alumina/10 $\mathrm{g}$ silica and $8 \mathrm{~g}$ alumina/10 $\mathrm{g}$ florisil columns resulted in lower \% recoveries compared to $4 \mathrm{~g}$ alumina/5 $\mathrm{g}$ silika and $4 \mathrm{~g}$ alumina/5 g florisil columns especially for 2,4-DDT and PCBs 138,153 and 180 . The best $\%$ recoveries were obtained from both GC-ECD and GC-MS when combination of $4 \mathrm{~g}$ alumina/5 $\mathrm{g}$ silica was used in extraction and clean-up step for 24DDT, PCB153 and PCB180.

Table 3. GC-ECD and GC-MS \% recoveries after clean-up process

\begin{tabular}{|c|c|c|c|c|c|c|}
\hline \multirow{3}{*}{ Pesticides } & \multicolumn{4}{|c|}{ GC-ECD } & \multirow{2}{*}{\multicolumn{2}{|c|}{$\begin{array}{c}\text { GC-MS } \\
\text { Recovery (\%) }\end{array}$}} \\
\hline & \multicolumn{4}{|c|}{ Recovery (\%) } & & \\
\hline & $\mathbf{A}$ & B & C & D & $\mathbf{A}$ & B \\
\hline HCB & 109.75 & 102.60 & 107.19 & 114.90 & 97.23 & 97.73 \\
\hline Dieldrin & 106.15 & 89.07 & 83.90 & 102.70 & 92.53 & 114.70 \\
\hline 24DDT & 84.05 & 88.43 & 64.28 & 73.00 & 110.73 & 73.23 \\
\hline PCB28 & 113.35 & 101.50 & 169.80 & 144.63 & 107.70 & 112.40 \\
\hline PCB52 & 106.10 & 106.17 & 112.13 & 119.33 & 99.33 & 115.40 \\
\hline PCB101 & 98.75 & 95.70 & 91.17 & 94.80 & 101.10 & 113.83 \\
\hline PCB118 & 113.03 & 105.63 & 89.53 & 93.30 & 101.77 & 126.33 \\
\hline PCB138 & 81.53 & 84.30 & 70.00 & 72.03 & 96.87 & 106.63 \\
\hline PCB153 & 91.85 & 85.90 & 55.75 & 74.80 & 96.67 & 81.90 \\
\hline PCB 180 & 118.10 & 106.02 & 73.83 & 100.00 & 91.13 & 59.35 \\
\hline
\end{tabular}

A: $4 \mathrm{~g}$ alumina/5 g silica. B: $4 \mathrm{~g}$ alumina/5 g florisil. C: $8 \mathrm{~g}$ alumina/10 $\mathrm{g}$ silica. D: $8 \mathrm{~g}$ alumina/10 $\mathrm{g}$ florisil 
The selectivity of the methods used was assessed by the analysis of six blank samples. No peaks of interfering compounds were observed within the intervals of the retention time of the analytes in any of these samples. Additionally, spiked samples with mix of standarts prepared at concentration of $5 \mu \mathrm{g} / \mathrm{kg}$ in isooctane were analysed using GC-MS. A typical chromatogram of spiked egg oil sample obtained from GC-MS is given in Figure 1.

Linearity was obtained from the triplicate injections matrixmatched calibration standard solutions at 5 levels $(0.5,10$, 15 and $20 \mu \mathrm{g} / \mathrm{kg}$ ) by using internal standard method. The correlation coefficients $\left(\mathrm{r}^{2}\right)$ were calculated in the range of 0.9564-0.9999 for GC-ECD and in the range of $=0.9701$ 0.9994 for GC-MS.

The accuracy was evaluated by recovery tests; analyzing fortified blank samples at the same concentration levels used in the precision tests $(5,10$ and $15 \mu \mathrm{g} / \mathrm{kg}$ in oil) for egg samples for GC-ECD and GC-MS. The accuracy and precision of the results of the method (Table 4) confirm to the values given in Decision 2002/657/EC. Thus, the mean accuracy values obtained in the recovery tests were between 86 and $116 \%$ and for intra-day $(n=6)$ study, RSDs were obtained in the range of 1.10-15.31\% and for inter-day study RSDs were obtained in the range of $2.73-17.51 \%$ from validation results obtained using GC-ECD as given in Table 4.

The mean accuracy values obtained in the recovery tests were between 81 and $116 \%$ and for intra-day (n=6), RSDs were obtained in the range of 0.30-7.20 and for inter-day study RSDs were obtained in the range of $1.20-10.10 \%$ from validation results obtained using GC-MS (Table 4). The precision of the method was determined in two stages: repeatability (intra-day) and intermediate precision (inter-day). Repeatability was expressed by the RSD of the results from six replicates analysed on the same day by the same analyst using the same instrument. The intermediate precision was expressed by the RSD of the results of eighteen analyses performed on three different days $(n=3)$, six analyses/day, by the same analyst using the same instrument.

Recovery tests at $10 \mu \mathrm{g} / \mathrm{kg}$ concentration $(\mathrm{n}=10)$ was done in GC-ECD, GC-MS and GC-MS/MS systems. The mean recoveries and RSDs were given at Table 5. Recovery was obtained in the range of 70-120\% and RSDs were obtained below at $20 \%$.

GC-ECD, GC-MS and GC-MS/MS methods have been applied to hundred egg samples and the analyses of OCP and
PCB congener's residues were determined. As a result of an efficient clean-up step, the interfering substances and background noise have been eliminated. Thus, the determination of each compound has been succeeded in high accuracy and precision. Nine egg samples showed the presence of $\beta$ $\mathrm{HCH}, 4,4-\mathrm{DDE}$ and PCB138. Quantification of the substances was carried out through the matrix-matched calibration curves by GC-ECD, obtained in terms of $\mu \mathrm{g} / \mathrm{kg}$ of sample according to the recovery values given in Table 5 . The highest concentration found was $30 \mu \mathrm{g} / \mathrm{kg}$ of 4,4-DDE in a sample obtained from Karaman. Other regions that OCP and PCB residues found in samples were Kayseri, Balıkesir, and Yozgat. Other than nine egg samples, the other results were always lower than the LOD values given in Table 6 . The detected amounts of $\beta-\mathrm{HCH}, 4,4-\mathrm{DDE}$ and $\mathrm{PCB} 138$ in nine egg samples were in the range of $5.1-7.2 \mu \mathrm{g} / \mathrm{kg}, 8.4-30$ $\mu \mathrm{g} / \mathrm{kg}$ and $4.2 \mu \mathrm{g} / \mathrm{kg}$ respectively.

The main analytical problem in chromatographic analysis of foods has been reported as the complexity of the matrix (Fugel et al., 2005) together with interfering co-extractive substances. These substances may deteriorate the chromatographic column (Garrido Frenich et al., 2006). Therefore, the analysis of OCPs and PCBs in egg samples involved a sample preparation step including a clean-up steps prior to extraction process.

The multi-residue methodology for the determination of 11 OCP and 7 PCB substances in egg samples by GC-ECD, GC-MS and GC-MS/MS using a clean-up process has been applied. Using matrix matched calibration procedure avoided matrix interference effects. Recoveries were found to be between $83 \%$ and $111 \%$. The LOQs of substances analysed were lower than the MRL established for eggs in the European Union. In agreement with the findings of Olanca et al. (2014), the detected amounts of OCP and BCB substances found in nine egg samples were found to be lower than MRLs set by EC (EC 2005, 2008, 2011).

Chan et al. (1996) analysed 51 PBC and 17 OCP in Thaleichthys pacificus oil using GC-MS and they found $\beta-\mathrm{HCH}$, 4-4 DDE and PCB138 at the range of 5-10, 30-70, and 2-6 $\mathrm{ng} / \mathrm{g}$ lipid respectively depending on the location where samples were collected. The amount of residues they have detected in fish oil samples seems lover when compared with the results of this study (from 4.2 to $30 \mu \mathrm{g} / \mathrm{kg}$ egg sample). The reason might be the differences in the concentration of these residues in feeding material of chicken and fish. 
Table 4. Method performance of GC-ECD and GC-MS (spike levels: 5,10 and $15 \mu \mathrm{g} / \mathrm{kg}$ )

\begin{tabular}{|c|c|c|c|c|c|c|c|c|c|c|c|c|c|c|c|c|c|c|}
\hline \multirow[b]{3}{*}{ Analyte } & \multicolumn{6}{|c|}{$5 \mu \mathrm{g} / \mathrm{kg}$} & \multicolumn{6}{|c|}{$10 \mu \mathrm{g} / \mathrm{kg}$} & \multicolumn{6}{|c|}{$15 \mu \mathrm{g} / \mathrm{kg}$} \\
\hline & \multicolumn{2}{|c|}{$\begin{array}{c}\text { Average } \\
\text { recovery }(\%)\end{array}$} & \multicolumn{2}{|c|}{$\begin{array}{c}\text { Intra-Day } \\
\text { precision } \\
(\text { RSD \%, n=6) }\end{array}$} & \multicolumn{2}{|c|}{$\begin{array}{c}\text { Inter-Day } \\
\text { precision } \\
(\text { RSD \%, n=18) }\end{array}$} & \multicolumn{2}{|c|}{$\begin{array}{c}\text { Average } \\
\text { recovery }(\%)\end{array}$} & \multicolumn{2}{|c|}{$\begin{array}{c}\text { Intra-Day } \\
\text { precision } \\
(\text { RSD \%, n=6) }\end{array}$} & \multicolumn{2}{|c|}{$\begin{array}{c}\text { Inter-Day } \\
\text { precision } \\
(\text { RSD \%, } \mathbf{n = 1 8})\end{array}$} & \multicolumn{2}{|c|}{$\begin{array}{c}\text { Average } \\
\text { recovery }(\%)\end{array}$} & \multicolumn{2}{|c|}{$\begin{array}{c}\text { Intra-Day } \\
\text { precision } \\
(\text { RSD\%, n=6) }\end{array}$} & \multicolumn{2}{|c|}{$\begin{array}{c}\text { Inter-Day } \\
\text { precision } \\
\text { (RSD \%, n=18 }\end{array}$} \\
\hline & $\begin{array}{l}\text { GC- } \\
\text { MS }\end{array}$ & $\begin{array}{l}\text { GC- } \\
\text { ECD }\end{array}$ & $\begin{array}{l}\text { GC- } \\
\text { MS }\end{array}$ & $\begin{array}{l}\text { GC- } \\
\text { ECD }\end{array}$ & $\begin{array}{l}\text { GC- } \\
\text { MS }\end{array}$ & $\begin{array}{l}\text { GC- } \\
\text { ECD }\end{array}$ & $\begin{array}{l}\text { GC- } \\
\text { MS }\end{array}$ & $\begin{array}{l}\text { GC- } \\
\text { ECD }\end{array}$ & $\begin{array}{l}\text { GC- } \\
\text { MS }\end{array}$ & $\begin{array}{l}\text { GC- } \\
\text { ECD }\end{array}$ & $\begin{array}{l}\text { GC- } \\
\text { MS }\end{array}$ & $\begin{array}{l}\text { GC- } \\
\text { ECD }\end{array}$ & $\begin{array}{l}\text { GC- } \\
\text { MS }\end{array}$ & $\begin{array}{l}\text { GC- } \\
\text { ECD }\end{array}$ & $\begin{array}{l}\text { GC- } \\
\text { MS }\end{array}$ & $\begin{array}{l}\text { GC- } \\
\text { ECD }\end{array}$ & $\begin{array}{l}\text { GC- } \\
\text { MS }\end{array}$ & $\begin{array}{l}\text { GC- } \\
\text { ECD }\end{array}$ \\
\hline Aldrin & 86 & 94 & 4,10 & 3,40 & 4,20 & 8,79 & 98 & 93 & 3,10 & 1,40 & 4,93 & 4,05 & 109 & 93 & 7,20 & 2,20 & 9,60 & 4,33 \\
\hline$\alpha-\mathrm{HCH}$ & 100 & 104 & 2,60 & 7,90 & 4,13 & 10,00 & 99 & 90 & 4,00 & 9,30 & 5,20 & 11,00 & 116 & 98 & 6,00 & 2,70 & 10,00 & 2,73 \\
\hline$\beta-\mathrm{HCH}$ & 108 & 98 & 4,80 & 15,31 & 7,90 & 15,67 & 97 & 90 & 6,10 & 4,90 & 7,90 & 6,95 & 104 & 96 & 2,40 & 4,00 & 9,50 & 8,87 \\
\hline$\gamma-\mathrm{HCH}$ (lindane) & 116 & 102 & 3,10 & 7,90 & 3,80 & 14,26 & 99 & 107 & 2,10 & 3,90 & 3,57 & 4,75 & 105 & 100 & 5,73 & 4,00 & 8,20 & 4,50 \\
\hline Dieldrin & 102 & 104 & 4,63 & 1,10 & 8,30 & 7,93 & 85 & 107 & 2,60 & 8,90 & 4,00 & 10,05 & 94 & 102 & 6,60 & 3,50 & 9,67 & 4,17 \\
\hline Heptachlor & 100 & 116 & 2,73 & 14,57 & 3,00 & 17,51 & 97 & 90 & 3,10 & 6,70 & 4,07 & 12,80 & 105 & 96 & 7,10 & 2,60 & 8,00 & 4,13 \\
\hline Heptachlorepoxide & 96 & 98 & 1,70 & 8,45 & 2,17 & 10,81 & 93 & 97 & 1,10 & 1,80 & 3,13 & 3,05 & 111 & 100 & 1,30 & 4,50 & 3,47 & 4,97 \\
\hline $\mathrm{HCB}$ & 106 & 96 & 1,50 & 4,40 & 3,50 & 5,76 & 100 & 103 & 2,10 & 5,70 & 4,37 & 7,00 & 108 & 98 & 6,00 & 3,70 & 7,40 & 4,13 \\
\hline 2,4-DDT & 100 & 94 & 2,70 & 1,80 & 3,00 & 6,05 & 79 & 110 & 2,30 & 4,10 & 2,63 & 4,20 & 86 & 100 & 5,00 & 4,50 & 7,57 & 6,20 \\
\hline 44-DDT & 100 & 96 & 3,77 & 3,80 & 4,30 & 7,50 & 75 & 105 & 5,00 & 4,05 & 5,07 & 8,20 & 95 & 100 & 6,20 & 4,50 & 7,10 & 8,45 \\
\hline 44-DDD & 110 & 86 & 1,90 & 8,45 & 1,90 & 14,28 & 90 & 103 & 1,40 & 1,10 & 1,97 & 5,70 & 95 & 102 & 6,50 & 2,40 & 8,47 & 3,73 \\
\hline 44-DDE & 102 & 102 & 0,80 & 6,18 & 1,30 & 8,44 & 94 & 103 & 2,00 & 4,70 & 2,37 & 7,80 & 94 & 96 & 5,70 & 2,75 & 7,53 & 3,27 \\
\hline PCB 28 & 102 & 95 & 2,23 & 7,66 & 2,30 & 11,51 & 96 & 109 & 1,90 & 1,60 & 2,23 & 3,70 & 97 & 100 & 5,77 & 3,60 & 6,80 & 6,60 \\
\hline PCB 30 & 106 & 92 & 2,00 & 4,02 & 3,37 & 9,82 & 101 & 104 & 2,20 & 1,50 & 3,47 & 2,95 & 116 & 101 & 6,80 & 3,20 & 10,10 & 4,53 \\
\hline PCB 52 & 104 & 94 & 0,60 & 5,00 & 1,93 & 7,67 & 96 & 100 & 2,20 & 1,90 & 2,40 & 4,05 & 97 & 101 & 5,20 & 2,10 & 5,97 & 5,47 \\
\hline PCB 101 & 100 & 99 & 1,50 & 6,32 & 1,60 & 8,60 & 93 & 105 & 1,70 & 0,90 & 2,07 & 7,20 & 92 & 100 & 4,20 & 3,80 & 5,83 & 5,93 \\
\hline PCB 118 & 106 & 96 & 2,30 & 5,34 & 4,40 & 10,57 & 93 & 105 & 0,30 & 1,30 & 1,43 & 2,55 & 91 & 99 & 3,30 & 1,30 & 5,60 & 3,40 \\
\hline PCB 138 & 108 & 94 & 1,30 & 3,20 & 1,73 & 6,62 & 96 & 105 & 1,40 & 0,20 & 2,67 & 3,50 & 95 & 94 & 6,10 & 3,50 & 7,27 & 3,60 \\
\hline PCB 153 & 104 & 93 & 1,13 & 4,15 & 1,30 & 5,45 & 81 & 100 & 2,30 & 0,40 & 3,03 & 4,85 & 91 & 101 & 5,20 & 1,70 & 6,07 & 5,87 \\
\hline PCB 180 & 106 & 94 & 0,83 & 5,20 & 1,20 & 6,76 & 84 & 97 & 1,77 & 0,50 & 2,20 & 2,50 & 88 & 94 & 0,70 & 2,10 & 6,77 & 3,10 \\
\hline
\end{tabular}

RSD: Relative standard deviation 


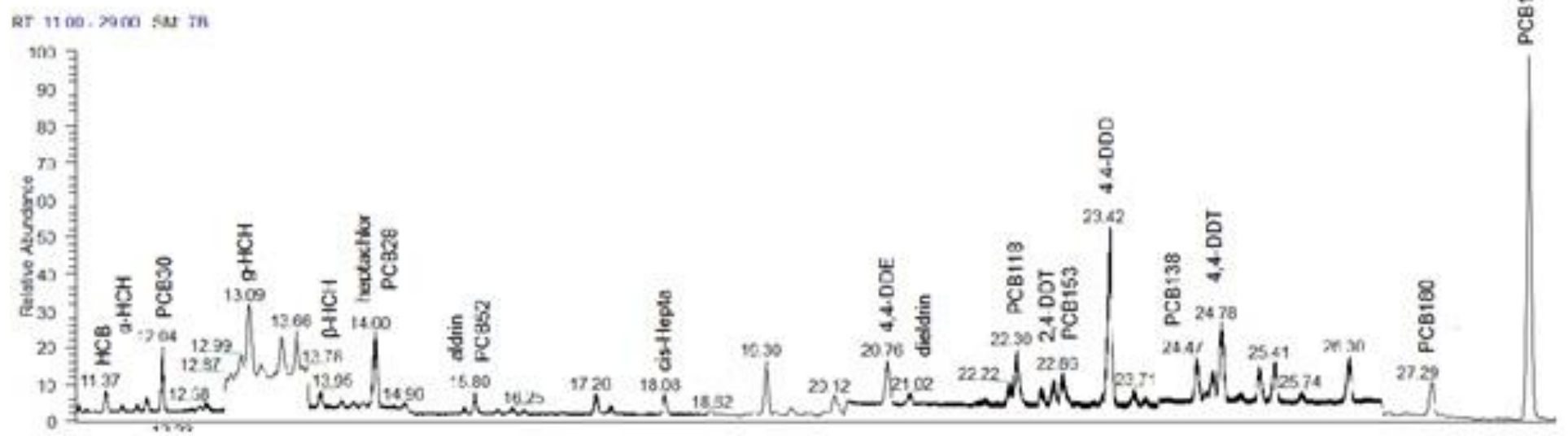

Figure 1. GC-MS chromatogram of mixture of OCPs and PCBs $(5 \mu \mathrm{g} / \mathrm{kg})$

Table 5. Recovery efficiencies of methods (spike level: $10 \mu \mathrm{g} / \mathrm{kg}$ )

\begin{tabular}{lcccccc}
\hline & \multicolumn{3}{c}{ Recovery (\%) } & \multicolumn{3}{c}{ RSD (\%) } \\
\cline { 2 - 7 } \multicolumn{1}{c}{ Nompound } & ECD & MS & MS/MS & ECD & MS & MS/MS \\
\hline Aldrin & 94 & 98 & 95 & 7.2 & 3.8 & 7.1 \\
$\alpha$-HCH & 90 & 97 & 104 & 10.4 & 4.9 & 14.1 \\
$\beta$-HCH & 89 & 98 & 102 & 8.5 & 5.6 & 7.7 \\
$\gamma$-HCH (lindane) & 104 & 99 & 111 & 4.1 & 2.8 & 9 \\
Dieldrin & 108 & 86 & 101 & 7.4 & 2.5 & 4.9 \\
Heptachlor & 91 & 99 & 96 & 7.1 & 2.9 & 7.3 \\
HCB & 102 & 97 & 95 & 7.0 & 5.0 & 7.9 \\
2.4-DDT & 110 & 84 & 99 & 5.7 & 2.4 & 8.2 \\
4.4-DDT & 103 & 83 & 94 & 7.5 & 5.4 & 11.3 \\
4.4-DDD & 101 & 92 & 102 & 6.5 & 0.9 & 7.6 \\
4.4-DDE & 103 & 94 & 96 & 5.4 & 1.8 & 7.2 \\
PCB 28 & 109 & 97 & 104 & 5.5 & 2.0 & 8.4 \\
PCB 30 & 103 & 99 & 111 & 4.1 & 2.9 & 6.6 \\
PCB 52 & 100 & 96 & 101 & 5.4 & 1.7 & 5.7 \\
PCB 101 & 105 & 94 & 101 & 8.9 & 1.6 & 9.7 \\
PCB 138 & 103 & 95 & 89 & 8.6 & 1.3 & 8.8 \\
PCB 153 & 99 & 85 & 92 & 8.7 & 2.4 & 8.5 \\
PCB 180 & 100 & 84 & 96 & 9.0 & 1.6 & 8.1 \\
\hline
\end{tabular}


Table 6. Limit of detections (LOD), limit of quantitations (LOQ) and correlation cofficients ( $\mathrm{R}^{2}$ ) of GC-MS and GC-ECD

\begin{tabular}{lcccccc}
\hline & \multicolumn{2}{c}{ Linearity $\left(\mathbf{R}^{\mathbf{2}}\right)$} & \multicolumn{2}{c}{$\mathbf{L O D}(\boldsymbol{\mu g} / \mathbf{k g})$} & \multicolumn{2}{c}{$\mathbf{L O Q}(\boldsymbol{\mu g} / \mathbf{k g})$} \\
\cline { 2 - 7 } Compound Name & GC-ECD & GC-MS & GC-ECD & GC-MS & GC-ECD & GC-MS \\
\hline Aldrin & 0.9862 & 0.9930 & 1.5 & 2.4 & 5.2 & 8.1 \\
$\alpha$-HCH & 0.9933 & 0.9973 & 2.5 & 1.7 & 5.2 & 5.8 \\
$\beta$-HCH & 0.9564 & 0.9854 & 2.5 & 1.5 & 7.5 & 4.9 \\
$\gamma$-HCH (lindane) & 0.9848 & 0.9982 & 2.5 & 1.2 & 8.4 & 4.0 \\
Dieldrin & 0.9873 & 0.9837 & 1.5 & 1.0 & 5.2 & 3.3 \\
Heptachlor & 0.9934 & 0.9897 & 2.2 & 1.9 & 7.5 & 6.3 \\
HCB & 0.9882 & 0.9935 & 1.5 & 0.9 & 5.2 & 3.0 \\
2.4 DDT & 0.9827 & 0.9753 & 3.1 & 1.0 & 10.0 & 3.5 \\
4.4 DDT & 0.9932 & 0.9701 & 3.5 & 1.6 & 7.2 & 5.2 \\
4.4 DDD & 0.9991 & 0.9829 & 2.5 & 0.9 & 5.1 & 3.0 \\
4.4 DDE & 0.9873 & 0.9900 & 1.5 & 1.2 & 5.2 & 4.0 \\
PCB 28 & 0.9939 & 0.9943 & 2.2 & 1.1 & 7.5 & 3.6 \\
PCB 30 & 0.9981 & 0.9994 & 2.3 & 0.9 & 7.2 & 3.1 \\
PCB 52 & 0.9956 & 0.9904 & 2.4 & 1.0 & 8.2 & 3.3 \\
PCB 101 & 0.9922 & 0.9909 & 1.9 & 1.2 & 6.3 & 3.9 \\
PCB 138 & 0.9949 & 0.9864 & 1.5 & 0.7 & 5.1 & 2.3 \\
PCB 153 & 0.9956 & 0.9881 & 1.2 & 0.6 & 4.1 & 2.1 \\
PCB 180 & 1.0000 & 0.9877 & 3.0 & 0.3 & 9.8 & 1.1 \\
\hline
\end{tabular}

Ahmad et al. (2010) analysed Organochlorine pesticide $(\mathrm{OCP})$ residues in eggs and meat samples from Jordan using GC-ECD. They found that $28 \%(38 / 134)$ of the examined eggs were contaminated with OCP residues and according to their study, mainly HCHs and DDTs were the most prominently noticed compounds. Percentage recovery in eggs after fortification at $100 \mu \mathrm{g} / \mathrm{kg}$ were in the range of $80-99 \%$ and LOD values were reported as $4-5 \mu \mathrm{g} / \mathrm{kg}$ which are slightly higher than LOD values obtained in this work. They detected $\mathrm{HCH}$ substances in 15 egg samples out of 134 at concentrations ranging from $6 \mu \mathrm{g} / \mathrm{kg}$ to $1.3 \mathrm{mg} / \mathrm{kg}$ egg. They have also reported DDE and DDT residues at $5 \mu \mathrm{g} / \mathrm{kg}-0.6$ $\mathrm{mg} / \mathrm{kg}$ concentrations. Some egg samples they analysed had higher residue concentrations than the samples analysed in this study which might be explained as the effect of geographic location where the samples collected.

Valsamaki et al. (2006) analysed 20 OCP and 8 PCB in chicken eggs using GC-ECD and GC-MS. The average recoveries they reported are ranging from 82 to $110 \%$ which are in a good agreement with the recoveries obtained in this study. They have reported the LOD and LOQ values as in the range of $0.3-0.7 \mu \mathrm{g} / \mathrm{kg}$ and $1.0-2.3 \mu \mathrm{g} / \mathrm{kg}$ respectively. In this study the LOD and LOQ values were found to be almost three fold of these values. The reason might be the difference in techniques used in sample preparation and clean-up procedures.

\section{Conclusions}

According to the data obtained by using GC-ECD, GC-MS and GC-MS/MS methods, it can be stated that the best repeatibility and recovery were provided by GC-MS technique. The clean-up procedure using $4 \mathrm{~g}$ alumina and $5 \mathrm{~g}$ silica columns gave best recoveries. Consequently, the best performance was obtained from clean-up process using alumina and silica combined columns prior to GC-MS method.

In this study, $\beta-\mathrm{HCH}, 4,4-\mathrm{DDE}$ and PCB138 were detected in nine egg samples out of hundred samples ranging from 4.2 to $30 \mu \mathrm{g} / \mathrm{kg}$. Although the detected amounts of residues were below the maximum residue levels (MRLs) permitted in foods, they have been banned for several years in countries of the European Union. Some of them are still present in the environment because of their persistent nature. The health risk of POP exposure through egg consumption was discussed elsewhere (Polder et al., 2016). Therefore, continuous monitoring of OCPs and PCBs residues in food materials is necessary and the monitoring procedures has been well established in many developed countries.

\section{Acknowledgement}

Technical support from Food Institute of the Scientific and Technological Research Council of Turkey (TÜBİTAK) is gratefully acknowledged. 


\section{References}

Ahmad, R., Salem, N. M., \& Estaitieh, H. (2010). Occurrence of organochlorine pesticide residues in eggs, chicken and meat in Jordan. Chemosphere, 78(6), 667-671.

Aulakh, R.S., Gill, J.P.S., Bedi, J.S., Sharma, J.K., Joia, B.S., Ockerman, H.W. (2006). Organochlorine pesticide residues in poultry feed, chicken muscle and eggs at a poultry farm in Punjab, India. Journal of the Science of Food and Agriculture, 86(5), 741-744.

Barriada-Pereira, M., González-Castro, M.J., MuniateguiLorenzo, S., López-Mahía, P., Prada-Rodríguez, D., Fernández-Fernández, E. (2005). Determination of organochlorine pesticides in horticultural samples by microwave assisted extraction followed by GC-ECD. International Journal of Environmental Analytical Chemistry, 85(4-5), 325-333.

Bernhoft, A., Wiig, O., Skaare, U. (1997). Organochlorines in Polar Bears (Ursus Maritimus) At Svalbard. Environmental Pollution, 95(2), 159-175.

Bolanos, P.P., Moreno, J.L.F., Shtereva, D.D., Frenich, A.G., Vidal, J.L.M. (2007). Development and validation of a multiresidue method for the analysis of 151 pesticide residues in strawberry by gas chromatography coupled to a triple quadrupole mass analyzer. Rapid Communications in Mass Spectrometry, 21(14), 2282-2294.

Chan, H.M., Khoury, M.El, Sedgemore, M., Sedgemore, S., Kuhnlein, H.V. (1996). Organochlorine Pesticides and Polychlorinated Biphenyl Congeners in Ooligan Grease: A Traditional Food Fat of British Columbia First Nations. Journal of Food Composition and Analysis, 9(1), 32-42.

Cortes-Aguado, S., Sanchez-Morito, N., Arrebola, F.J., Frenich, a G., Vidal, J.L.M. (2008). Fast screening of pesticide residues in fruit juice by solid-phase microextraction and gas chromatography-mass spectrometry. Food Chemistry, 107, 1314-1325.

Çok, I., Yelken, Ç., Durmaz, E., Üner, M., Sever, B., SatIr, F. (2011). Polychlorinated biphenyl and organochlorine pesticide levels in human breast Milk from the mediterranean city Antalya, Turkey. Bulletin of Environmental Contamination and Toxicology,
$86(4), 423-427$.

Darko, G., Acquaah, S.O. (2007). Levels of organochlorine pesticides residues in meat. International Journal of Environmental Science \& Technology, 4(4), 521-524.

Fernandes, V.C., Domingues, V.F., Mateus, N., DelerueMatos, C. (2011). Determination of pesticides in fruit and fruit juices by chromatographic methods. An overview. Journal of Chromatographic Science, 49(October), 715-730.

Fernandes, V. C., Domingues, V. F., Mateus, N., \& DelerueMatos, C. (2012). Analysing organochlorine pesticides in strawberry jams using GC-ECD, GC-MS/MS and QuEChERS sample preparation. Food Additives and Contaminants - Part A Chemistry, Analysis, Control, Exposure and Risk Assessment, 29(7), 1074-1084.

Fontcuberta, M., Arqués J.F., Villalbí, J.R., Martínez, M., Centrich, F., Serrahima, E., Pineda, L., Duran, J. Casas, C. (2008). Chlorinated organic pesticides in marketed food: Barcelona, 2001-06. Science of the Total Environment, 389(1), 52-57.

Fugel, R., Carle, R., Schieber, A. (2005). Quality and authenticity control of fruit purees, fruit preparation and jams--a review. Trends in Food Science \& Technology., 16(10), 433-441.

Garrido Frenich, A., Martínez Vidal, J.L., Cruz Sicilia, A.D., González Rodríguez, M.J., Plaza Bolaños, P. (2006). Multiresidue analysis of organochlorine and organophosphorus pesticides in muscle of chicken, pork and lamb by gas chromatography-triple quadrupole mass spectrometry. Analytica Chimica Acta, 558(1-2), 42-52.

Jeong, Y., Lee, S., Kim, S., Choi, S.D., Park, J., Kim, H.J., Lee, J.J., Choi, G., Choi, S., Kim, S., Kim, S.Y., Kim, Y.D., Cho, G., Suh, E., Kim, S.K., Eun, S.H., Eom, S., Kim, S., Kim, G.H., Choi, K., Kim, S., Moon, H.B. (2014). Occurrence and exposure assessment of polychlorinated biphenyls and organochlorine pesticides from homemade baby food in Korea. Science of the Total Environment, 470-471, 1370-1375.

Keikotlhaile, B.M., Spanoghe, P., Steurbaut, W. (2010). Effects of food processing on pesticide residues in 
fruits and vegetables: A meta-analysis approach. Food and Chemical Toxicology, 48(1), 1-6.

Kilic, D., Cakıroğulları, G.Ç., Uçar, Y., Theelen, R., Traag, W. (2011). Comparison of PCDD/F and dl-PCB levels in Turkish foodstuffs: industrial versus rural, local versus supermarket products, and assessment of dietary intake. Food Additives \& Contaminants. Part A, Chemistry, Analysis, Control, Exposure \& Risk Assessment, 28(7), 913-24.

Liu, H., Zhang, Q., Wang, Y., Cai, Z., Jiang, G. (2007). Occurrence of polychlorinated dibenzo-p-dioxins, dibenzofurans and biphenyls pollution in sediments from the Haihe River and Dagu Drainage River in Tianjin City, China. Chemosphere, 68(9), 1772-1778.

Mansilha, C., Melo, A., Rebelo, H., Ferreira, I.M., Pinho, O., Domingues, V., Pinho, C., Gameiro, P. (2010). Quantification of endocrine disruptors and pesticides in water by gas chromatography-tandem mass spectrometry. Method validation using weighted linear regression schemes. Journal of Chromatography A, 1217(43), 6681-6691.

Nasir, K., Bilto, Y.Y., Al-Shuraiki, Y. (1998). Residues of chlorinated hydrocarbon insecticides in human milk of Jordanian women. Environmental Pollution, 99(2), 141-148.

Olanca, B., Cakirogullari, G.C., Ucar, Y., Kirisik, D., Kilic, D. (2014). Polychlorinated dioxins, furans (PCDD/Fs), dioxin-like polychlorinated biphenyls (dl-PCBs) and indicator PCBs (ind-PCBs) in egg and egg products in Turkey. Chemosphere, 94, 13-19.

Polder, A., Müller, M.B., Brynildsrud, O.B., de Boer, J., Hamers, T., Kamstra, J.H., Lie, E., Mdegela, R.H., Moberg, H., Nonga, H.E., Sandvik, M., Skaare, J.U., Lyche, J.L. (2016). Dioxins, PCBs, chlorinated pesticides and brominated flame retardants in freerange chicken eggs from peri-urban areas in Arusha, Tanzania: Levels and implications for human health. Science of the Total Environment, 551-552, 656-667.
Ritter, L., Solomon, K. R., Forget, J., Stemeroff, M., O'Leary, C. (1995). A Review of Selected Persistent Organic Pollutants. Apostila, (December), 1-149.

Salem, N.M., Ahmad, R., Estaitieh, H. (2009). Organochlorine pesticide residues in dairy products in Jordan. Chemosphere, 77(5), 673-678.

Tao, S., Liu, W.X., Li, X.Q., Zhou, D.X., Li, X., Yang, Y.F., Yue, D.P., Coveney, R.M. (2009). Organochlorine pesticide residuals in chickens and eggs at a poultry farm in Beijing, China. Environmental Pollution, 157(2), 497-502.

Vallack, H.W., Bakker, D.J., Brandt, I., Broström-Lundén, E., Brouwer, A., Bull, K.R., Gough, C., Guardans, R., Holoubek, I., Jansson, B., Koch, R., Kuylenstierna, J., Lecloux, A., Mackay, D., McCutcheon, P., Mocarelli, P., Taalman, R.D. (1998). Controlling persistent organic pollutants-what next? Environmental Toxicology and Pharmacology, 6(3), 143-175.

Valsamaki, V.I., Boti, V.I., Sakkas, V.A., Albanis, T.A. (2006). Determination of organochlorine pesticides and polychlorinated biphenyls in chicken eggs by matrix solid phase dispersion. Analytica Chimica Acta, 573-574, 195-201.

Wong, J.W., Zhang, K., Tech, K., Hayward, D.G., Krynitsky, A.J., Cassias, I., Schenck, F.J., Banerjee, K., Dasgupta, S., Brown, D. (2010). Multiresidue pesticide analysis of ginseng powders using acetonitrile- or acetone-based extraction, solid-phase extraction cleanup, and gas chromatography-mass spectrometry/selective ion monitoring (GC-MS/SIM) or -tandem mass spectrometry (GC-MS/MS). Journal of Agricultural and Food Chemistry, 58(10), 58845896. 